\title{
STUDIES ON THE NUTRIENT CONTENT OF TREELESS SPHAGNUM PAPILLOSUM BOGS
}

\author{
Armi Kaila, JaAkko Kivekäs, Kalevi Virri and Erkki Kivinen \\ University of Helsinki, Department of Agricultural Chemistry
}

Received March 8, 1957

The classification of virgin peat lands on the basis of surface vegetation, first introduced in Finland by CAJANDER (1) and later developed e.g. by PaAsio (7), Kivinen (5) and LukKala and Kotilainen (6), has proved to be a valuable aid to the investigation of peat lands both for practical and scientific purposes. Nature, however, is not inclined to be fitted into man-made categories. Therefore, also the peat land vegetation types are only conventional groups within which the variations of several characteristics may be quite marked.

The treeless bogs in which Sphagnum papillosum is the dominating moss form a manifold group called in Finnish "kalvakkanevat" or pallid treeless bogs on account of the pale brown colour peculiar to this moss. At present these bogs are divided into three main groups (5 p. $76-77)$ :

1. The proper Sphagnum papillosum treeless bogs

2. Molinia-Sphagnum papillosum treeless bogs

3. Mesotrophic Sphagnum papillosum treeless bogs

On the basis of the dominating species of Cyperaceae the first of these groups is further divided into five subordinate types:

a. Carex lasiocarpa (or Carex rostrata) - Sphagnum papillosum bogs

b. Carex limosa-Sphagnum papillosum bogs

c. Scirpus caespitosus-Sphagnum papillosum bogs

d. Eriophorum vaginatum-Sphagnum papillosum bogs

e. Sphagnum papillosum bogs invaded by Sphagnum fuscum

Sphagnum papillosum, the moss which is typical to these bogs, appears to be an oligotrophic-mesotrophic species, able to grow even under rather poor conditions (8, p. 117). Thus it gives only little information of the land quality which mainly depends on the composition of the sedge and herb vegetation. According to the present opinion (5) all the proper Sphagnum papillosum treeless bogs have a fairly low degree of quality: from 2 to 4 . The Molinia-Sphagnum papillosum bogs are estimated to represent the degrees from 5 to 6 , and the mesotrophic type may even have a somewhat higher degree or $6-7$. 
As far as the authors know, no detailed study exists of the nutrient content in the S. papillosum treeless bogs in Finland. It was therefore found advisable to publish the present results obtained by analysing 35 series of samples collected from the various depths of virgin $S$. papillosum treeless bogs.

\section{Material and methods}

The samples studied in the present work mainly came from Sphagnum papillosum bogs in Northern Finland and Ostrobothnia. In order to study thoroughly the quality of these bogs samples were taken from three layers $(1-3 \mathrm{dm}, 4-6$ $\mathrm{dm}$, and $8-10 \mathrm{dm}$ ) and also from the mixed surface vegetation.

The peat type and the degree of humification were determined by direct examination of the fresh samples on the field. The $\mathrm{pH}$ values were measured in the laboratory from fresh samples using a Beckman $\mathrm{pH}$-meter with glass electrode. All the other analyses were performed after the samples had been air-dried at room temperature and ground in a Wiley mill. The analytical methods employed for the determination of total nitrogen, phosphorus and extractable cations were the same as those in previous papers ( 2 and 3 ).

The following list gives some information about the bogs and the peat samples:

N:o Place $\quad$ Bo $\quad 1-3 \mathrm{dm} \quad 4-6 \mathrm{dm} \quad 8-10 \mathrm{dm}$

\section{Eriophorum vaginatum-Sphagnum papillosum bogs}

$\begin{aligned} 1 & \text { Ylikiiminki } \\ 6 & \text { Sievi } \\ 15 & \\ 16 & \text { Haapajärvi } \\ 32 & \text { Taivalkoski }\end{aligned}$

$\begin{array}{llllll}\text { ErSp } & \mathrm{H}_{4} & \text { ErSp } & \mathrm{H}_{5} & \text { ErSp } & \mathrm{H}_{6} \\ \text { ErSp } & \mathrm{H}_{2} & \text { ErSp } & \mathrm{H}_{3} & \text { ErSp } & \mathrm{H}_{3} \\ \text { ErSp } & \mathrm{H}_{4} & \text { ErSp } & \mathrm{H}_{6} & \text { ErSp } & \mathrm{H}_{7} \\ \text { ErCSp } & \mathrm{H}_{2} & \text { ErCSp } & \mathrm{H}_{3} & \text { ErCSp } & \mathrm{H}_{5} \\ \text { Sp } & \mathrm{H}_{1} & \text { Sp } & \mathrm{H}_{3} & \text { SCp } & \mathrm{H}_{5}\end{array}$

2. Scirpus caespitosus-Sphagnum papillosum bogs

\begin{tabular}{|c|c|c|c|c|c|}
\hline 9 & Sievi & 3 & $\mathrm{SC}_{\mathrm{p}} \mathrm{H}_{\mathbf{3}}$ & $\mathrm{SCp} \mathrm{H}_{3}$ & $\mathrm{SC}_{\mathrm{p}}$ \\
\hline 10 & , & 3 & $\mathrm{SC}_{\mathrm{p}} \mathrm{H}_{3}$ & $\mathrm{SCp} \mathrm{H}_{3}$ & $\mathrm{SC}_{\mathrm{p}}$ \\
\hline 11 & , & 3 & $\mathrm{SC}_{\mathrm{p}} \mathrm{H}_{4}$ & $\mathrm{SCp} \mathrm{H}_{4}$ & $\mathrm{SC}_{\mathrm{p}}$ \\
\hline 29 & Kuhmo & $3-4$ & $\mathrm{SCp} \mathrm{H}_{1}$ & $\mathrm{SCp} \mathrm{H}_{4}$ & $\mathrm{SC}_{\mathrm{p}}$ \\
\hline 31 & Taivalkoski & $1-2$ & $\mathrm{Sp}$ & $\operatorname{CSp~} \mathrm{H}_{3}$ & $\mathrm{CSp}$ \\
\hline 33 & Sodankylä & 2 & Sp $\mathrm{H}_{3}$ & $\mathrm{Cp}_{\mathrm{p}} \mathrm{H}_{3}$ & $\mathrm{Cp}_{\mathrm{p}}$ \\
\hline 36 & Vaala & 3 & CSp $\mathrm{H}_{3}$ & $\mathrm{CSp} \mathrm{H}_{8}$ & \\
\hline
\end{tabular}

3. Carex limosa-Sphagnum papillosum bogs

\begin{tabular}{|c|c|c|c|c|c|}
\hline 2 & Pudasjärvi & 3 & $\operatorname{CSp} \mathrm{H}_{2}$ & $\mathrm{CSp} \mathrm{H}_{4}$ & $\operatorname{CSp} \mathrm{H}_{6}$ \\
\hline 3 & , & 5 & $\mathrm{SCp} \mathrm{H}_{2}$ & $\mathrm{SC}_{\mathrm{p}} \mathrm{H}_{3}$ & $\mathrm{SC}_{\mathrm{p}} \mathrm{H}_{6}$ \\
\hline 21 & , & $1-2$ & $\mathrm{CSp} \mathrm{H}_{4}$ & $\mathrm{CSp} \mathrm{H}_{4}$ & CSp $\mathrm{H}_{5}$ \\
\hline 22 & , & 3 & $\mathrm{CSp} \mathrm{H}_{4}$ & $\mathrm{CSp}_{4}$ & $\mathrm{CSp}_{5}$ \\
\hline 23 & Rovaniemi & $1-2$ & CSp $\mathrm{H}_{1}$ & $\mathrm{CSp} \mathrm{H}_{3}$ & $\mathrm{CSp} \mathrm{H}_{3}$ \\
\hline 28 & Kuhmo & 4 & $\mathrm{SCp} \mathrm{H}^{4}$ & $\mathrm{SC}_{\mathrm{p}} \mathrm{H}_{3}$ & $\mathrm{SC}_{\mathrm{p}} \mathrm{H}_{6}$ \\
\hline 30 & Suomussalmi & $\begin{array}{ll}3-4 \\
-1\end{array}$ & $\mathrm{SCp} \mathrm{H}_{2}$ & $\mathrm{LC}_{\mathrm{p}} \mathrm{H}_{3}$ & $\mathrm{Cp}_{\mathrm{p}}$ \\
\hline
\end{tabular}


N:o Place $\quad$ Bo $\quad 1-3 \mathrm{dm} \quad 4-6 \mathrm{dm} \quad 8-10 \mathrm{dm}$

4. Carex lasiocarpa-Sphagnum papillosum bogs

\begin{tabular}{|c|c|c|c|c|}
\hline Sievi & 4 & $\mathrm{SC}_{\mathrm{p}} \mathrm{H}_{2}$ & $\mathrm{SC}_{\mathrm{p}} \mathrm{H}_{3}$ & $\mathrm{SC}_{\mathrm{p}} \mathrm{H}_{3}$ \\
\hline 7 & 6 & $\mathrm{SC}_{\mathrm{p}} \mathrm{H}_{4}$ & $\mathrm{SC}_{\mathrm{p}} \mathrm{H}_{6}$ & $\mathrm{SC}_{\mathrm{p}} \mathrm{H}_{\mathrm{s}}$ \\
\hline , & 5 & $\mathrm{SC}_{\mathrm{p}} \mathrm{H}_{4}$ & $\mathrm{SC}_{\mathrm{p}} \mathrm{H}_{4}$ & $\mathrm{SC}_{\mathrm{p}} \mathrm{H}_{3}$ \\
\hline 12 & 5 & $\mathrm{SC} \mathrm{H}_{3}$ & $\mathrm{SC}_{\mathrm{p}} \mathrm{H}_{4}$ & $\mathrm{SC}_{\mathrm{p}} \mathrm{H}_{4}$ \\
\hline Haapajärvi & 5 & $\mathrm{SCp} \mathrm{H}_{4}$ & $\mathrm{SC}_{\mathrm{p}} \mathrm{H}_{4}$ & $\mathrm{SCp} \mathrm{H}_{\mathrm{s}}$ \\
\hline Pudasjärvi & 4 & $\mathrm{SC}_{\mathrm{p}} \mathrm{H}_{2}$ & $\mathrm{SC}_{\mathrm{p}} \mathrm{H}_{\mathbf{3}}$ & $\mathrm{SC}_{\mathrm{p}} \mathrm{H}_{4}$ \\
\hline 20 & 5 & $\mathrm{SC}_{\mathrm{p}} \mathrm{H}_{4}$ & $\mathrm{SC}_{\mathrm{p}} \mathrm{H}_{5}$ & $\mathrm{SC}_{\mathrm{p}} \mathrm{H}_{6}$ \\
\hline Kuhmo & $3-4$ & $\mathrm{SC}_{\mathrm{p}} \mathrm{H}_{3}$ & $\mathrm{SC}_{\mathrm{p}} \mathrm{H}_{2}$ & $\mathrm{SC}_{\mathrm{p}} \mathrm{H}_{2}$ \\
\hline Salla & $5-6$ & $\mathrm{Cp}_{\mathrm{p}} \mathrm{H}_{2}$ & $\mathrm{Cp}_{\mathrm{p}} \quad \mathrm{H}_{3}$ & - \\
\hline Vaala & $3-4$ & $\mathrm{SCp} \mathrm{H}_{3}$ & $\mathrm{LC}_{\mathrm{p}} \mathrm{H}_{\mathrm{s}}$ & - \\
\hline
\end{tabular}

5. Mesotrophic Sphagnum papillosum bogs

\begin{tabular}{|c|c|c|c|c|c|c|}
\hline 25 & Rovaniemi & 5 & $\mathrm{SC}_{\mathrm{p}}$ & $\mathrm{H}_{4}$ & $\mathrm{SC}_{\mathrm{p}} \mathrm{H}_{\mathrm{s}}$ & $\mathrm{SC}_{\mathrm{p}}$ \\
\hline 26 & , & 4 & $\mathrm{SC}_{\mathrm{p}}$ & $\mathrm{H}_{3}$ & $\mathrm{SC}_{\mathrm{p}} \mathrm{H}_{4}$ & $\mathrm{SC}_{\mathrm{p}}$ \\
\hline 37 & Kemijärvi & $4-5$ & $\mathrm{SCp}$ & $\mathrm{H}_{1}$ & $\mathrm{SC}_{\mathrm{p}} \mathrm{H}_{6}$ & $\mathrm{Cp}_{\mathrm{p}}$ \\
\hline 38 & , & $5-6$ & EuSCp & $\mathrm{H}_{4}$ & $\mathrm{SC}_{\mathrm{p}} \mathrm{H}_{6}$ & $\mathrm{SC}_{\mathrm{p}}$ \\
\hline 39 & , & $5-6$ & $\mathrm{Cp}_{\mathrm{p}}$ & $\mathrm{H}_{3}$ & $\mathrm{C}_{\mathrm{p}} \quad \mathrm{H}_{6}$ & $\mathrm{Cp}_{\mathrm{p}}$ \\
\hline
\end{tabular}

6. Molinia- Sphagnum papillosum bog
40
Kemijärvi
6
$\mathrm{LSCP}_{3}$
$\mathrm{LC}_{\mathrm{p}} \mathrm{H}_{\mathrm{s}}$
LCp $\mathrm{H}_{7}$

The proper Sphagnum papillosum treeless bogs form the main part of this material. Unfortunately samples of only one Molinia-bog were available. Also the group of the mesotrophic Sph. papillosum bogs is not large.

The Bo-values, or the degrees of land quality, were determined by the collectors of the samples in the field. Too much attention must not be paid to these values owing to the subjectiveness which, of course, plays a part in this kind of determination.

The remains of Sphagnum appear to be dominating in the peat samples of the Eriophorum vaginatum-Sph. papillosum bogs. In the other groups of the proper Sph. papillosum bogs also the sedges are of importance as the raw material of peat. This is particularly true with the Carex lasiocarpa-Sph. papillosum bogs and then, of course, with the mesotrophic groups.

\section{Results}

The results of analyses are presented in Figures $1-3$. Owing to the rather small number of samples in the various bog-groups it was not considered reasonable to employ any thorough statistical treatment of the data, and so only the average for each characteristic were calculated. In addition to the mean values also the corresponding minimium and maximum values for every group are reported in the figures. 

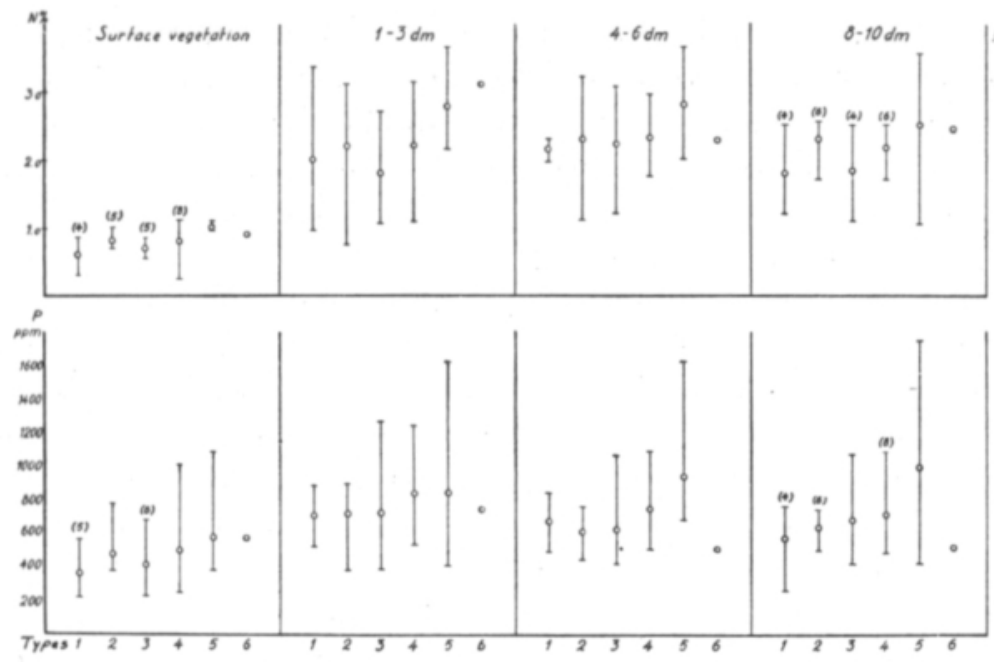

Fig. 1. Acidity and ash content in the different layers of the various groups of Sph. papillosum bogs. $\mathrm{o}=$ average value, $-=$ minimum and maximum values. In brackets numbers of samples in defective groups.
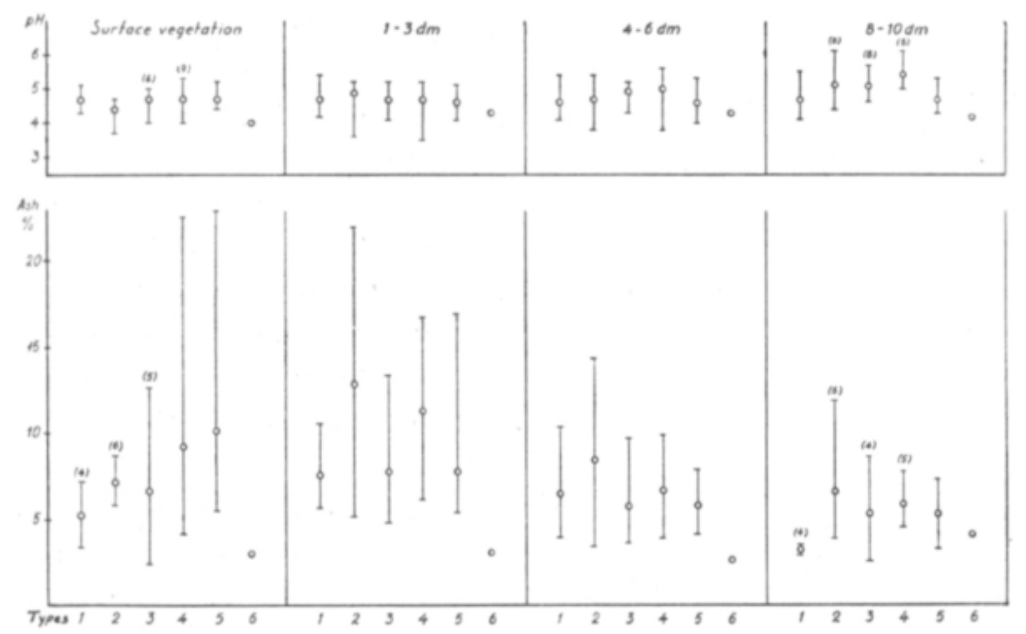

Fig. 2. Total nitrogen and phosphorus content in the different layers of the various groups of $S p h$. papillosum bogs. $\mathrm{o}=$ average value, $-=$ minimum and maximum values. In brackets numbers of samples in defective groups.

In Figure 1 the acidity of the fresh samples is presented. In most of the cases the $\mathrm{pH}$-values of one group vary within rather narrow limits. The mean $\mathrm{pH}$-values for all the groups and various layers lie between $\mathrm{pH} 4$ and $\mathrm{pH} 5$, except in peat samples from a depth of 8-10 dm, among which in three cases somewhat higher average $\mathrm{pH}$-values can be found. Yet, on the basis of these data there is, obviously, no reason to assume any significant differences between the acidity of the various groups of Sph. papillosum treeless togs. 
The same figure also gives the ash content of the samples. On account of a few samples containing a high amount of ash the variation in some groups is considerable. The Eriophorum vaginatum-group, 1 , tends to show a somewhat lower ash content than the others, particularly in the deepest layer, and perhaps also in the surface vegetation. Generally the ash content is of the same order as it usually is in Finnish virgin peat soils ( 1 and 4$)$. Significant differences between the ash contents in the samples of the various bog groups cannot be stated.

The total nitrogen content of the surface vegetation is low (Fig. 2) in all the peat lands in spite of the herbs and sedges in the groups 5 and 6 . Probably this is due to the dominating moss, Sphagnum papillosum known to be low in nitrogen (4). The peat of the mesotrophic bogs appears to be fairly rich in nitrogen, but in the poorer groups the maximum nitrogen percentages are also high, rising to even more than 3 per cent of the dry matter.
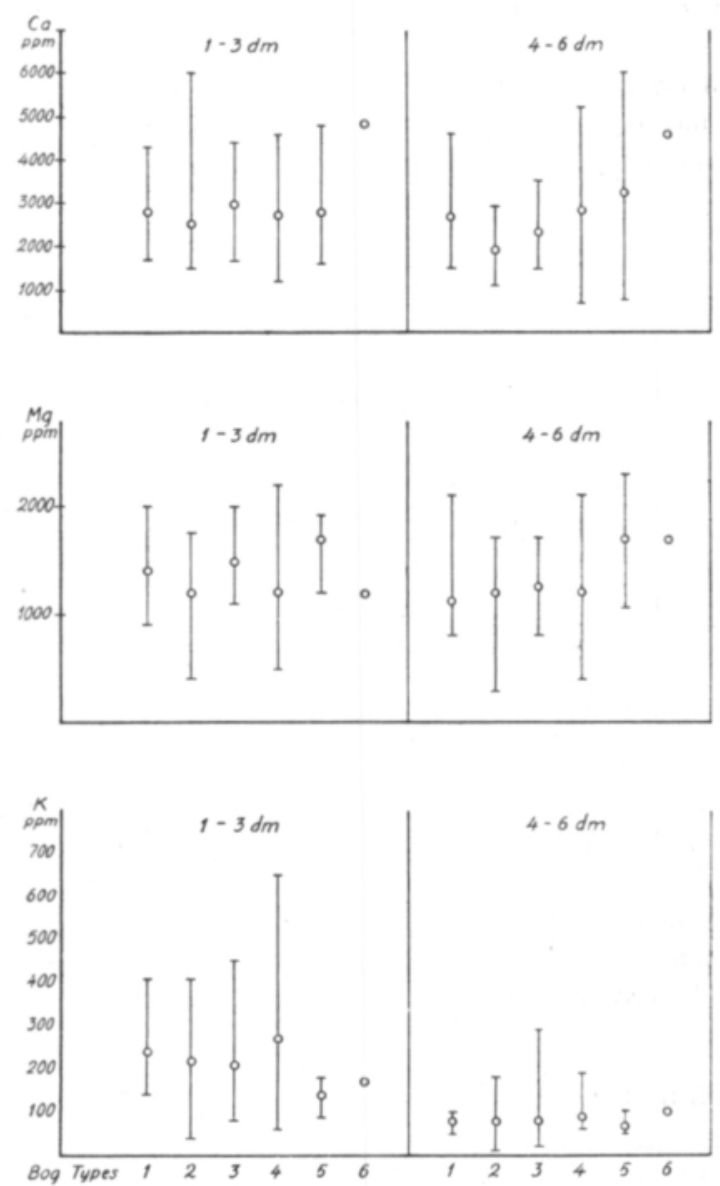

Fig. 3. Calcium, magnesium, and potassium extractable with ammonium chloride solutiom from the peat samples of various groups of Sph. papillosum bogs. o = average value, $-=$ minimum and maximum values.
As to the total phosphorus content of the samples, the highest values are found in the group of mesotrophic bogs. The corresponding differences in the mean values of the various groups are, however, insignificant.

The respective average amounts of calcium, magnesium, and potassium extracted by $1 \mathrm{~N}$ ammonium chloride solution from the peat samples of the different bog groups (Fig. 3 ) are almost equal, too. Thus even in this respect there seems to be no significant difference between the various kinds of Sph. papillosum bogs.

A more detailed study concerning the phosphorus conditions in these peat lands was also performed. The results are not reported here, since they agree entirely with the results obtained above; on the basis of the present material it is not possible to find out any significant differences between the nutrient contents of the various $S p h$. papillosum treeless bogs.

\section{Discussion}

When this study was planned it was expected to find at least some 
differences in the nutrient contents of the various types of the Sph. papillosum treeless bogs. The present results do not confirm this supposition. On the basis of these analytical data it is impossible to decide whether the samples in question belong to a peat land group of a higher or a lower quality.

It may be claimed, of course, that the present material is not typical enough of the various groups of Sph. papillosum treeless bogs. This, perhaps, is true, but it means that also in nature the peat lands are not always so very typical representatives of their classes. The variation within one group is large in every respect and there are often more or less mixed surface vegetation types. Although it is sometimes possible to find differences between a few representatives of various kinds of peat land, it is often found that when a larger quantity of material is studied the overlapping of the characteristics is marked.

Another explanation of the present results may be found in the domination of Sph. papillosum in the surface vegetation. Thus the amount of the other plant species was small compared with that of the moss, and the differences in their composition were not analytically detectable in the mixed masses. In the peat samples the domination of the $S p h$. papillosum remains is even more marked, due to their rather slow decomposition.

\section{S $u m m$ ary}

The present paper reports the results of analyses of the nutrient contents of Finnish treeless Sph. papillosum bogs. 35 peat lands which represented 6 types of these bogs were analyzed for $\mathrm{pH}$, ash content, total nitrogen and phosphorus content, and for their content of calcium, magnesium, and potassium extractable by $1 \mathrm{~N}$ ammonium chloride.

According to the results obtained no significant differences existed between the six types of Sph. papillosum bogs.

The reasons for this chemical equality of the peat lands with different surface vegetation is discussed.

\section{REFERENCES}

(1) Cajander, A. K. 1913. Studien über die Moore Finlands. Acta forest. fenn. 2,3. 208 p. Helsinki.

(2) KaIlA, A. 1956. Phosphorus in virgin peat soils. J. Sci. Agr. Soc. Finland 28: 142-167.

(3) —— \& KrveKäs, J. 1956. Distribution of extractable calcium, magnesium, potassium, and sodium in various depths of some virgin peat soils. Ibid. $28: 237-247$.

(4) Kivinen, E. 1933. Suokasvien ja niiden kasvualustan kasvinravintoainesuhteista. Referat: Untersuchungen über den Gehalt an Pflanzennährstoffen in Moorpflanzen und an ihren Standorten. Acta agr. fenn. 27.

(5) $\longrightarrow$ 1948. Suotiede. 219 p. Porvoo.

(6) Lukkala, O. J. \& Kotilainen, M. J. 1951. Soiden ojituskelpoisuus. 64 p. Helsinki. 
(7) Passio, I. 1936. Suomen nevasoiden tyyppijärjestelmää koskevia tutkimuksia. Acta forest. fenn. 44,3: ]-129.

(8) Тиомгкозкі, R. 1946. Suomen rahkasammalista ja niiden tuntemisesta ilman mikroskooppia. Luonnon ystävä $50: 113-117,150-159$.

\section{SELOSTUS :}

\section{HAVAINTOJA KALVAKKANEVOJEN RAVINTEISUUDESTA}

\section{Armi Kaila, JaAkKo Kivekäs, Kalevi Virri ja Erkki Kivinen}

Yliopiston Maanviljelyskemian laitos, Helsinki

Tutkimuksessa kåsitellään 35 suolta, lähinnä pohjois-Suomen kalvakkanevoilta, eri syvyyksistă otettujen turvenäytteiden sekä pintakasvuston $\mathrm{pH}: \mathrm{n}$, tuhkapitoisuuden, totaalitypen ja -fosforin, sekä 1-n $\mathrm{NH}_{4} \mathrm{Cl}$ :lla uuttuvan kalsiumin, magnesiumin ja kaliumin măäriä.

Tulosten perusteella ei tutkittujen kuuden kalvakkanevatyypin ravinteisuudessa havaita merkitseviä eroja. 